\title{
Voice teacher's artistic-pedagogical proficiency in the terminological field of scientific research
}

\author{
Tao Rui, H. Nikolai \\ South Ukrainian national pedagogical university named after K.D. Ushynsky \\ *Corresponding author. Email: galanikolayi@gmail.com
}

Paper received 20.06.21; Accepted for publication 30.06.21.

\section{https://doi.org/10.31174/SEND-HS2021-253IX45-19}

\begin{abstract}
The article makes an attempt to organize the conceptual-terminological field of research of the phenomenon of "voice teacher's artistic-pedagogical proficiency" in order to give the most appropriate definition. It is proved that a voice teacher's artisticpedagogical proficiency is a qualitative characteristic of his professional competence, which is manifested in a specific set of qualities necessary for successful teaching in music pedagogy and concerns teaching students the interpretation of artistic images by means of vocal technique and free possession of pedagogical technique.
\end{abstract}

Keywords: voice teacher, pedagogical proficiency, vocal proficiency, artistic-pedagogical proficiency, artistic-aesthetic education, pedagogical aesthetics, vocal-pedagogical technique.

Introduction. The specifics of the pedagogical activity of a voice teacher requires from the higher education institution graduate an ability to perform it skillfully, which provides for his comprehensive training both in the field of musical art and pedagogy. An important result of such training is acquisition by the applicant of artisticpedagogical proficiency in fulfilling the functions of a voice teacher. The latter, i.e. a voice teacher's artisticpedagogical proficiency, we understand as an integrative quality of the personality, consisting of a value attitude to vocal heritage, competence in the field of vocal pedagogy, vocal-performance culture and vocal-pedagogical techniques.

At the same time, the results of a careful analysis of a large array of theoretical works have shown the lack of a clear thesaurus in the problem field of research of performing-pedagogical proficiency of music teachers. It is also established that the problem of forming the voice teacher's artistic-pedagogical proficiency has not yet become the subject of investigation. Therefore, the relevance of the proposed article is beyond doubt.

Analysis of relevant research. Analysis of a wide range of sources has shown the attention of scientists to the problem of teachers' pedagogical proficiency. In particular, it is represented in the works of Ye. Barbina, I. Ziaziun, L. Korol, O. Lavrinenko, O. Romaniuk, N. Tarasevych and others. A. Kozyr carried out a comprehensive and thorough analysis of the theory and practice of forming professional proficiency of music teachers in the system of multilevel education. The problems of performing skills formation in future music teachers in different types of musical activity were investigated by L. Labintseva, I. Mostova, Yu. Nekrasov, V. Fedoryshyn, and in the context of comparative research - Liu Chang and Zhang Xiangyong. Some issues of vocal skills formation were considered in the works of such well-known researchers as V. Antoniuk, N. Ovcharenko, O. Sleptsova, O. Stakhevych and others. Scientists have convincingly proved that higher education is designed to lay a solid foundation for pedagogical proficiency of future art specialists, which gives a significant socio-cultural effect.

The category of "artistic" is often used in research on various aspects of future music teachers' vocal training. Thus, in Luo Chao's dissertation, the latter is explored using the "artistic method of personification", which allows the author to comprehend cultural processes "through immersion in the collective image of the hero (person)" and to reflect "own artistic-creative possibilities in interpreting and creating such an image" [9].

B. Nahai argues that the artistic image of a musical work is an integrated reflection of the author's idea in the mind of the performer and is determined by the subjective vision and sense of reality of the latter. Moreover, to embody the artistic image, each performer uses a whole system of means of artistic expression [10]. O. Opanasiuk identifies five stages of structuring the artistic image (principle, formation, definition, method, existence), believing that this structure is the optimal structure of the artistic image and the work of art in general and corresponds to the optimal structural parameters of the human psyche [15]. K. Klimai believes that in space-time coordinates the artistic image in music is "a ratified concentrate of spiritual energy, each time unique, rediscovered and just as interesting for human consciousness". In the interpretation of the artistic image in music, Yu. Chekan proposes to take into account its receptive component ("meaningful in individual experience"). The scientist considers the artistic image in music as a central methodological category, as an "intonation image of the world".

A review of publications on the topic of the article has shown that some of them have a category of aesthetic. Thus, V. Piddiachyi is convinced that in order to achieve pedagogical proficiency, a teacher must engage in professional self-development, in particular - on an aesthetic basis [16]. H. Sotska studies the principles of future teachers' aesthetic culture formation [18], V. Onyshchenko initiates a new branch of pedagogical science - pedagogical aesthetics as a theory of aesthetic education [14].

We believe that identifying the essence of the voice teacher's artistic-pedagogical proficiency requires, first of all, a comprehensive conceptual-terminological analysis of relevant scientific works of domestic researchers, including dissertations as the most valid sources, which contain English translations of the concepts of interest. We also see the need for semantic analysis of English vocabulary literature in order to find analogues of the concepts "pedagogical proficiency", "vocal proficiency", 
"artistic-aesthetic education", "pedagogical aesthetics", "vocal-pedagogical technique".

Thus, the aim of the article is to organize the conceptual-terminological field of research of the phenomenon of "voice teacher's artistic-pedagogical proficiency" in order to give the most appropriate definition.

Materials and methods. Among the materials used in the article, dissertation research on the problems of pedagogical proficiency and vocabulary literature predominate. The research methodology is based on such general scientific approaches as axiological, culturological and comparative. The article presents a number of analytical methods, in particular conceptualterminological and semantic-comparative analysis of the basic terms, as well as methods of systematization and generalization.

Results and discussion. A significant result has become introduction of a new method of comparativeterminological analysis with systematic use of materials of dissertation research, dictionary literature and Cyrillic in texts with Latin. It is emphasized that one of the most difficult problems of comparative studies is the search for terminological analogues in the translation of the scientific thesaurus. For our research adequate translation of basic concepts into English is important. The results of conceptual-terminological and semantic-comparative analysis have shown the differences in the use of Englishlanguage analogues of basic terms in dissertations on the phenomenon of pedagogical proficiency.

Thus, in the thesis of L. Labintseva [5] vocal-choral proficiency (Ukr. - вокально-хорова майстерність) is translated into English by the term "vocally-choral trade". In one of the first dissertations (1998), which explored the problems of forming the pedagogical proficiency of the future music teacher, in particular his pedagogicalperforming proficiency, I.V. Mostova even the title of the work translates in different ways - both into Russian “Формирование педагогического и исполнительского мастерства будущего учителя музыки” and English "Mastery learning of teaching and performing proficiency for future music teacher".

In O. Lavrinenko's doctoral dissertation "The tendencies of the development of the ideas of teacher's pedagogical skills: theory and practice (the middle of the 16 th - the end of the 20th century), which summed up the results of many years of research by Ukrainian scholars on the problem of pedagogical proficiency of teachers, the latter is translated as "teacher's pedagogical skills" []. In his dissertation research, Liu Chang considers the English analogue of the term "pedagogical proficiency" to be "pedagogical skills". In an abstract in English, the scientist notes: "It was found that in the first and second years, students mainly train basic skills to improve their musical achievements, and in the third and fourth years, they focus on the development of musical expression, creativity and pedagogical skills" [8].

A. Kozyr in her doctoral thesis [3] translates teacher's professional proficiency as a "professional trade" as well as V. Fedoryshyn [21]. Terminological diversity is also observed in English-language abstracts to dissertations of other researchers. Thus, L. Korol uses the concept of "pedagogical mastership" [4], O. Romaniuk considers the
English analogue of the term "pedagogical proficience" to be the concept of "pedagogical mastery" [17], Zhang Xiangyong translates artistic-performing proficiency as "artistic and performance skills" [22]. Recall also that in our previous studies, we used the term "formation of pedagogical mastery" [20].

The analysis of the dictionary literature has shown that the term педагогічна майстерність (Ukr.) has several synonyms: skills, mastery, mastership, trade, proficiency. Oxford Advanced Learner's Dictionary [25] gives the following definitions of the above terms:

skill - the ability to do something well;

mastery - great knowledge about or understanding of a particular thing;

- proficiency - the ability to do something well because of training and practice.

Furthermore, it doesn't give any definition to the term mastership, while the proposed definitions of the term trade (1) the activity of buying and selling or of exchanging goods or services between people or countries; 2) a particular type of business; 3) a particular area of business and the people or companies that are connected with it; 4) the amount of goods or services that you sell; 5) a job, especially one that involves working with your hands and that requires special training and skills) don't reveal the essence of the Ukrainian term педагогічна майстерність.

Cambridge Dictionary [24] gives similar definitions of the terms under discussion.

skill - an ability to do an activity or job well, especially because you have practiced it;

mastery - if someone has a mastery of something, they are extremely skilled at it;

- proficiency - the fact of having the skill and experience for doing something.

This dictionary also doesn't provide any definition of the term mastership, and also proves misunderstanding by Ukrainian researchers of the term "trade".

Thus, we consider the most appropriate term to denote the key concept of our study to be "proficiency".

In the terminological field of our research the first component of the concept of artistic-pedagogical proficiency occupies an important place. The analysis of dictionary literature and scientific publications has shown that Ukrainian term художній "artistic" is synonymous with the concept of мистецький "artistic", which is used in the Ukrainian scientific space as a derivative of the term "art" (мистеитво). Note that in the Russianlanguage scientific literature there is no analogue, because the term "artificial" (искусственньй) has a completely different meaning. Along with the total spread in Ukraine of the concept of "art education" (Ukrainian мистецька освіт», Russian художественное образование), the term художній is increasingly being replaced in the scientific and pedagogical literature by мистецький, while in English they are both translated as artistic. However, when it comes to the specific properties of the figurative sphere of art, its aesthetic impact on the personality and creative attribution (activity), the term художній remains relevant.

In her doctoral dissertation, N. Ovcharenko, studying the phenomenon of future music teachers' readiness for vocal and educational activities, singles out, among 
others, the semiotic-hermeneutic component, which is "aimed at systematic study of musical and poetic language of the vocal work, identification of its artistic meaning and creation of performance interpretation of the vocal work" [13, p. 405].

The category of artistic is often used in the dissertation research on various aspects of voice training of future music teachers. Luo Chao's dissertation "Methods of the future musical art teachers' vocal training by means of personification technology" is no exception. Luo Chao argues that this technology is a significant methodological resource that increases the effectiveness of the educational process. Extrapolation of personification as an artistic method to the future music teachers' voice training allows to comprehend cultural processes "through immersion in the collective image of the hero (person)" and reflection of "one's own artistic and creative possibilities in the interpretation and creation of such an image" [9].

In the process of clarifying the meaning of the concept of artistic-pedagogical proficiency, we have paid attention to the dialectic of artistic and aesthetic in the interpretation of pedagogical proficiency. Thus, V. Piddiachyi is convinced that in order to achieve pedagogical proficiency, a teacher must engage in professional self-development, in particular - on an aesthetic basis [16]. In this case, it is appropriate to mention D. Diderot's opinion, who argued that the beauty of the ideal amazes everyone without exception, and the beauty of proficiency can be appreciated only by experts. The main difference between proficiency and ideal, the famous encyclopedist saw in the fact that proficiency wins the attention of a specialist, and the ideal - his soul [1].

In comparative terms, we recall the opinion of $\mathrm{H}$ Sotska that modern art education is actively moving from professional-scientific to universal-humanitarian model, according to which in the process of creating a personality, dominant importance acquires the aesthetic component of this model, and the content of the educational process acquires aesthetic and value coloring [18]. It becomes obvious that the terminological field of our research also has an aesthetic dimension. Among the definitions of the aesthetic as a fundamental category, we are impressed by the characteristics of O. Losev, who distinguishes between "expression" and "expressiveness", i.e. materialization of a particular idea, translation of internal to external [7]. A prominent phenomenologist argues that aesthetics, dealing with the sensory cognition of the universe, is not limited to the realm of beauty, but also includes in its scope disgusting, tragic, comic, etc. and is "the science of expression in general" [ibid.].

According to the results of a comparative analysis of the interpretation of the categories "aesthetic" and "artistic" in the foreign scientific thought, we can say the following. If the aesthetic in nature, in material culture and in man is manifested in form, then in the work of art the aesthetic is doubled, it is present both in form and in content. Common to the phenomena of aesthetic and artistic we consider such factors as sensory-emotional and rational-logical beginnings, as well as isomorphism of structures that include the processes of perception, cognition, evaluation and transformation.
In comparative terms, it is clear that on the one hand, the aesthetic is the basis of the artistic. On the other hand, in the ratio of artistic and aesthetic, the latter is broader, as it characterizes the diverse spheres of human life. However, it is the products of artistic activity, masterpieces of art, evoking aesthetic feelings, affect the spiritual world of man and are the highest manifestation of the aesthetic.

With regard to vocal art, the generic concept of our study is the concept of "musical-aesthetic", the essence of which is sound expressiveness. Note that in the process of centuries of evolution of the aesthetic, the musical language was transformed accordingly. Thus, the sense of harmony in the classics is replaced by a tragic worldview in the romantics, while in the postmodernists the irrational vision of the world is reflected in the desire for "total collage" (D. Albright). In general, in music of the twentieth century intensifies the sphere of disgusting, horrible, embodied in the dissonances of the cosmic scale. On the other hand, the growth of the degree of freedom of "sound expression" of the composer's worldview reaches its culmination today. Everyone can create his own ideals of musical and aesthetic.

Thus, in the terminological search for related categories to the "artistic", it is impossible to avoid its connection with the concept of "aesthetic". In the theoretical understanding of the latter we turn to use the heuristic possibilities of a comparative analysis. An example of the active use of the scientific apparatus of aesthetics is the art pedagogy of Poland.

In general, development of art education in Poland has long been defined by the concept of aesthetic education and has strong roots in the traditions of the European humanism. The terminological discourse of Polish scientific thought in historical retrospect testifies to the following transformations of concepts: Władysław Tatarkiewicz's theory of aesthetic experience (przeczucie); Roman Ingarden's multiphase structure of aesthetic experience; Stefan Schumann's education through art, empowerment (upowczechnianie), sharing (udostępnianie) and accessibility (uprzystępniania) of art); Bohdan Sukhodolsky's education through experience, aesthetic vulnerability, aesthetic education, education through art; Irena Voynar's education for art (wychowanie do sztuki) and education through art (wychowanie przez sztukę), aesthetic vulnerability [12].

In Ukraine, modern art education is theoretically realized in the socio-cultural context, and the aesthetic categorical apparatus of post-Soviet aesthetics is now being actively rethought, taking into account the achievements of idealist philosophy. In this regard, the "father" of aesthetics as an independent science, the German philosopher and art theorist Alexander Gottlieb Baumgarten, defined the essence of aesthetics through the concept of perfect, not through the concept of beautiful. It should be noted that Baumgarten defined the subject of aesthetics in two projections, claiming that it studies the laws of sensory cognition (philosophical projection) and artistic creativity (artistic projection) [23].

In his theory of aesthetic education, V. Sukhomlynskyi emphasized that it covers absolutely all spheres of human spiritual life. A well-known Ukrainian educator stated: "The most important task of aesthetic education is to 
teach a child to see in the beauty of the world spirituality, kindness, cordiality and on this basis to assert the beautiful in oneself" [19].

Academician I. Ziaziun, one of the founders of the philosophy of education in Ukraine, stressed: "The specificity of aesthetic education lies in the fact that it exists in other types of education and is manifested through other forms, as the most common in education, without which education is unthinkable" and further: "The set of norms is usually perceived as an external factor, and the value is an internal, aesthetic, assimilated by the subject of lifelong reference and is perceived as its own spiritual intention" [2]. Following I. Ziaziun, we claim that only a harmonious combination of knowledge, experiences and attitudes in the content of education can ensure the solution of its problems.

The founder of philosophical-pedagogical noology V. Onyshchenko combined in his concept the ideas of Christian personalism and hermeneutics. The scholar believes that in the field of art education the transcendental categories of Truth, Good, Beauty are concretized in the conditions of a specially organized meeting with artistic reality. According to $\mathrm{V}$. Onyshchenko, it is the Divine Transcendental Triad (Truth, Good, Beauty) that gives rise to the basic noological categories of rationality-ethics-aesthetics in their inseparable trinity [14]. The scientist convincingly substantiates the status of a new branch of pedagogical science - pedagogical aesthetics as a theory of aesthetic education of pupils and students [ibid., p. 173].

We agree with V. Onyshchenko that the principle of Spirit and spirituality includes the fullness of rationality, which requires not only clear logic, but also life-giving intuition, ethics, which becomes flawed without faith, and aesthetics, which in addition to the laws of beauty is also based on the gospel commandment of love. In turn, each of these categories is concretized in new triads imagination-intuition-mind (rationality); faith-consciencewill (ethics); love-joy-hope (aesthetics) [ibid., p. 183].

In the terminological field of scientific search for the definition of the voice teacher's artistic-pedagogical proficiency, we also include the concept of vocalpedagogical technique. Since musical-performing and pedagogical functions coexist in the activity of a voice teacher, vocal-performing and pedagogical techniques are usually studied separately. We believe that they are integrated in such qualities of a voice teacher as sound formation technique, articulation, facial expressions and pantomime, self-control over body movements, operation of signals from analyzers, as well as creativity and volitional self-regulation.

According to the results of comparative analysis it is established that one of the effective ways to form such a component of artistic-pedagogical proficiency of future vocal teachers as vocal-pedagogical technique is the technology of transition from speech to singing voice formation through mastering the elements of stage language.

Generalization of scientific thought allows us to argue that artistic-pedagogical proficiency of a voice teacher is a way to realize his musical-performing and socio-cultural experience in the development of pedagogical reality. Artistic-pedagogical proficiency of a voice teacher is a qualitative characteristic of his professional competence, which is manifested in a specific set of qualities necessary for successful teaching in music pedagogy and concerns teaching students the interpretation of artistic images by means of vocal technique and free possession of pedagogical technique.

Conclusions. The results of conceptual-terminological and semantic-comparative analysis have shown the differences in the use of English-language analogues of the basic terms in dissertations on the phenomenon of pedagogical proficiency. The English-language analogue of the term художньо-педагогічна майстерність is considered to be "artistic-pedagogical proficiency", because its semantics corresponds to the essential meaning of the defined Ukrainian concept.

Artistic-pedagogical proficiency of a voice teacher is a qualitative characteristic of his professional competence, which is manifested in a specific set of qualities necessary for successful teaching in the field of music pedagogy, including interpretation of artistic images by the vocal technique and free possession of the pedagogical technique. The latter are integrated in such qualities of a voice teacher as sound formation technique, articulation, facial expressions and pantomime, self-control over body movements, operation of signals from analyzers, as well as creativity and volitional self-regulation.

\section{REFERENCES}

1. Дидро Д. Собр. соч.: в 10 т. Т.6: Искусство. Москва; Ленград, 1946.

2. Зязюн I.А. Естетичні засади розвитку особисті. Мистецтво у розвитку особистості. Чернівці: Зелена Буковина, 2006.

3. Козир А. В. Теорія та практика формування професійної майстерності вчителів музики в системі багаторівневої освіти: автореф. дис. ... докт. пед. наук. Київ, 2009.

4. Король Л. Л. Розвиток педагогічної майстерності як складової професійної підготовки майбутнього вчителя в Полтавському педагогічному інституті (1970-1990 pp. ХХ ст.). Харків, 2007.

5. Лабінцева Л. П. Формування вокально-хорової майстерності в процесі фахової підготовки майбутніх учителів музики: автореф. дис. ... канд. пед. наук. Луганськ, 2007.

6. Лавріненко О.А. Тенденції розвитку ідей педагогічної майстерності вчителя: теорія і практика (середина XVIкінець ХХ ст.). Київ, 2009.
7. Лосев А. Ф. История античной эстетики. Итоги тысячелетнего развития.

URL: http://psylib.ukrweb.net/books/lose008/txt14.htm.

8. Лю Чан. Формування професійно-педагогічної культури майбутніх учителів музичного мистецтва у закладах вищої освіти КНР: дис. ... доктора філософії. Харків, 2021.

9. Ло Чао. Методика вокальної підготовки майбутніх учителів музичного мистецтва засобами технології персоніфікації: автореф. дис. ... канд. пед. наук. Суми, 2018.

10. Нагай Б. Сутність художнього образу в музичному мистецтві // Актуальні питання гуманітарних наук. 2017. № 17 Мистецтвознавство.

11. Некрасов Ю. І. Комплексний підхід до формування виконавської майстерності піаніста: автореф. дис. ... канд. мистецтвознавства. Одеса.

12. Ніколаї Г.Ю. Розвиток музично-педагогічної освіти в Польщі (XX століття): дис. ... докт. пед. наук. Київ, 2008. 
13. Овчаренко Н. А. Теоретико-методологічні засади професійної підготовки майбутніх учителів музичного мистецтва до вокально-педагогічної діяльності: дис. ... докт. пед. наук. Київ, 2016.

14. Онищенко В. Д. Фундаментальні педагогічні теорії. Львів: Норма, 2014.

15. Опанасюк О. П. Онтологічні аспекти структури художнього образу // Ставропігійські філософські студії. Збірник наукових праць 3 філософії, психології, мистецтвознавства, культурології, педагогіки та філософії освіти, 2008. № 1. С. 49-62.

16. Піддячий В. М. Естетичні засади професійного саморозвитку майбутнього педагога: дис. ... канд. пед. наук. Київ, 2016.

17. Романюк О. І. Розвиток педагогічної майстерності викладачів економічних дисциплін в умовах магістратури: дис. ... канд. пед. наук. Київ, 2020.

18. Сотська Г.I. Теоретичні і методичні засади формування естетичної культури майбутніх учителів в педагогічних університетах: автореф. дис. ... докт. пед. наук. Київ, 2014.

\section{REFERENCES TRANSLATED AND TRANSLITERATED}

1. Diderot D. Sobr. soch.: v 10 t. T.6: Yskusstvo. Moskva; Lenhrad, 1946.

2. Ziaziun, I. A. (2006). Estetychni zasady rozvytku osobysti. Mystetstvo u rozvytku osobystosti. Chernivtsi: Zelena Bukovyna.

3. Kozyr, A. V. (2009). Teoriia ta praktyka formuvannia profesiinoi maisternosti vchyteliv muzyky $\mathrm{v}$ systemi bahatorivnevoi osvity: avtoref. dys. ... dokt. ped. nauk. Kyiv.

4. Korol, L.L. (2007). Development of pedagogical mastership as the component of professional training of future teacher in Poltava pedagogical institute $(1970-1990$ XX cent.) $(\mathrm{PhD}$ thesis). Kharkiv.

5. Labintseva, L. P. (2007). Formation of vocally-choral trade in the process of the special preparation of future music masters (PhD thesis abstract). Lugansk.

6. Lavrinenko, O. A. (2009). The tendencies of the development of the ideas of the teacher's pedagogical skills: theory and practice (the middle of the 16th - the end of the 20th century). Kyiv.

7. Losev, A. F. Ystoryia antychnoi эstetyky. Ytohy tosiacheletneho razvytyia.

URL: http://psylib.ukrweb.net/books/lose008/txt14.htm.

8. Liu Chan (2021). Formuvannia profesiino-pedahohichnoi kultury maibutnikh uchyteliv muzychnoho mystetstva u zakladakh vyshchoi osvity KNR: dys. ... doktora filosofii. Kharkiv.

9. Luo Chao. (2018). Methods of the future musical art teachers' vocal training by means of personification technology $(\mathrm{PhD}$ thesis). Odesa.

10. Nahai, B. (2017). Sutnist khudozhnoho obrazu v muzychnomu mystetstvi // Aktualni pytannia humanitarnykh nauk. № 17 Mystetstvoznavstvo.

11. Nekrasov, Yu. I. Kompleksnyi pidkhid do formuvannia vykonavskoi maisternosti pianista: avtoref. dys. ... kand mystetstvoznavstva. Odesa.
19. Сухомлинський В. О. Павлиська середня школа // Вибрані твори у 5-ти томах. К.: Вища школа, 1977. Т. 4.

20. Тао Жуй. Теоретико-методологічні основи формування педагогічної майстерності студентів-вокалістів // Педагогічні науки: теорія, історія, інноваційні технології. 2018. № 10 (84). С. 190-199.

21. Федоришин В.I. Формування виконавської майстерності студентів музично-педагогічних факультетів у процесі колективного музикування: автореф. дис. ... канд. пед. наук. Київ, 2006.

22. Чжан Сянюн. Формування художньо-виконавської майстерності майбутніх піаністів з КНР у процесі фахової підготовки у вищих педагогічних навчальних закладах України: дис. ... канд. пед. наук. Суми, 2016.

23. Baumgarten A. Ästhetik. Bd. 2, § 614 - 904; übers. von D. Mirbach. Hamburg : Meiner, 2007.

24. Cambridge Dictionary.

URL: https://dictionary.cambridge.org/dictionary/english/.

25. Oxford Advanced Learner's Dictionary. URL: https://www.oxfordlearnersdictionaries.com/definition/englis $\mathrm{h} /$.

12. Nikolayi, H. Y. (2008). The Development of Musical Pedagogical Education in Poland (20th century) (DSc thesis). Kyiv.

13. Ovcharenko, N. A. (2016). Theoretical and methodological basis of training future teachers of music to vocal and educational activities (DSc thesis). Kyiv.

14. Onyshchenko, V. D. (2014). Fundamentalni pedahohichni teorii. Lviv: Norma.

15. Opanasiuk, O. P. (2008). Ontolohichni aspekty struktury khudozhnoho obrazu // Stavropihiiski filosofski studii. Zbirnyk naukovykh prats $\mathrm{z}$ filosofii, psykholohii, mystetstvoznavstva, kulturolohii, pedahohiky ta filosofii osvity. № 1. S. 49-62.

16. Piddiachyi, V. M. (2016). Aesthetic Basis for the Professional Self-Development of a Future Pedagogue $(\mathrm{PhD}$ thesis). Kyiv.

17. Romaniuk, O. I. (2020). Developing pedagogical mastery of economics teachers in master's degree programs ( $\mathrm{PhD}$ thesis). Kyiv.

18. Sotska, H. I. (2014). Teoretychni i metodychni zasady formuvannia estetychnoi kultury maibutnikh uchyteliv $\mathrm{v}$ pedahohichnykh universytetakh: avtoref. dys. ... dokt. ped. nauk. Kyiv.

19. Sukhomlynskyi, V. O. (1977). Pavlyska serednia shkola // Vybrani tvory u 5-ty tomakh. K.: Vyshcha shkola. T. 4.

20. Tao Rui. Teoretyko-metodolohichni osnovy formuvannia pedahohichnoi maisternosti studentiv-vokalistiv // Pedahohichni nauky: teoriia, istoriia, innovatsiini tekhnolohii. 2018. № 10 (84). S. 190-199.

21. Fedoryshyn, V. I. (2006). Forming of trade of students of mouzichno-pedagogichnih faculties carrying out in the process of collective mouzicouvannya ( $\mathrm{PhD}$ thesis). Kyiv.

22. Zhang Xiangyong (2016). The formation of artistic and performance skills of pianists from PRC in the process of professional training in higher pedagogical educational establishments of Ukraine (PhD thesis). Sumy. 